\title{
Tuz stresi ve bor toksisitesi koşulları altında yetişen soya bitkisine yapılan bakteri ve melatonin uygulamasının toprak mikrobiyal aktivitesine etkisi
}

\section{Effect of bacteria and melatonin application on soil microbial activity on soybean plants grown under salt stress and boron toxicity conditions}

\author{
Ali SARIOĞLU1*iD, Cengiz KAYA ${ }^{1}$ iD \\ ${ }^{1,2}$ Harran Üniversitesi, Ziraat Fakültesi, Toprak Bilimi ve Bitki Besleme Bölümü, Şanlıurfa/Türkiye \\ ${ }^{1}$ https://orcid.org/0000-0001-6269-4990; ${ }^{2 h t t p s: / / o r c i d . o r g / 0000-0001-8938-3463 ~}$
}

To cite this article:

Sarıoglu, A. \& Kaya, C. (2021). Tuz stresi ve bor toksisitesi koşulları altında yetişen soya bitkisine yapılan bakteri ve melatonin uygulamasının toprak mikrobiyal aktivitesine etkisi. Harran Tarım ve Gıda Bilimleri Dergisi, 25(3): 335-348.

DOI: 10.29050/harranziraat.929285

*Address for Correspondence: Ali SARIOĞLU

e-mail:

asarioglu@harran.edu.tr

Received Date:

28.04.2021

Accepted Date:

05.07.2021

(C) Copyright 2018 by Harran University Faculty of Agriculture. Available on-line at www.dergipark.gov.tr/harranziraat öz

Bu çalışmada, tuz stresi (TS) ve bor toksisitesi (BT) şartlarında soya bitkisine yapraktan yapılan melatonin (MT) uygulaması ve tohumdan bakteri aşılamasının bitki gelişimi ile topraktaki bazı mikrobiyal aktivitelere etkisi araştırılmıştır. Bu araştırma sera denemesi olarak toprak ortamında saksılarda yürütülmüştür. Araştırma konuları; kontrol, TS (100mM NaCl), BT (2mM B) ve $\mathrm{TS}+\mathrm{BT}(100 \mathrm{mM} \mathrm{NaCl}+2 \mathrm{mM} \mathrm{B})$ olarak belirlenmiştir. Araştırma sonuçlarına göre, soya bitkisinde en fazla zarar TS+BT birlikte uygulamasında görülmüştür. Genel olarak yapılan stres uygulamaları bitki yaş ve kuru ağılıklarında ve $\mathrm{DHA}, \mathrm{MBC}$ ve $\mathrm{CO}_{2}$ gibi toprak mikrobiyal aktivite içeriklerinde önemli azalmaya neden olmaktadır. Bunun yanı sıra, stres etkilerine karşı yapılan uygulamalardan özellikle bakteri aşılaması (BA) stresin etkilerini hafifletmede etkili olduğu belirlenmiştir. Bununla birlikte yapılan melatonin (MT) uygulaması ise, tek başına BA uygulaması kadar etkili olmamış fakat BA ile stres etkilerini daha fazla azaltmada destek görevi görmüştür. Yapılan BA ve MT uygulamaları ile soya bitkisinde, bitki yaş ve kuru ağırlıklarında ve toprak mikrobiyal aktivitelerinde ( $\mathrm{DHA}, \mathrm{MBC}$ ve $\mathrm{CO}_{2}$ ) artışlar olduğu tespit edilmiş ve bu artışlar istatistiki $(P \leq 0.05)$ olarak önemli bulunmuştur.

Anahtar Kelimeler: Tuz stresi, Bor toksisitesi, Melatonin, Soya, Bakteri

\section{ABSTRACT}

In this study, the effects of foliar melatonin (MT) application to soybean plant and bacterial inoculation from seed on plant growth and some microbial activities in soil were investigated under salt stress (SS) and boron toxicity (BT) conditions. This research was carried out in pots in the soil environment as a greenhouse experiment. Research topics; control was designated as SS $(100 \mathrm{mM} \mathrm{NaCl}), \mathrm{BT}(2 \mathrm{mM} \mathrm{B})$ and $\mathrm{SS}+\mathrm{BT}(100 \mathrm{mM} \mathrm{NaCl}+2 \mathrm{mM} \mathrm{B})$. According to the results of the research, the most damage was seen in the combined application of SS+BT in soybean plant. In general, stress applications cause a significant decrease in plant fresh and dry weights and soil microbial activity contents such as $\mathrm{DHA}, \mathrm{MBC}$ and $\mathrm{CO}_{2}$. In addition, it has been determined that especially bacterial inoculation (BA), which is one of the applications against the effects of stress, is effective in alleviating the effects of stress. However, the application of melatonin (MT) was not as effective as the application of BA alone, but it served as a support in further reducing the effects of stress with $B A$. It was determined that there were increases in plant fresh and dry weights and soil microbial activities (DHA, $\mathrm{MBC}$ and $\mathrm{CO}_{2}$ ) in soybean plant with $\mathrm{BA}$ and $\mathrm{MT}$ applications, and these increases were found to be statistically significant $(\mathrm{P} \leq 0.05)$.

Key Words: Salt stress, Boron toxicity, Melatonin, Soybean, Bacteria 


\section{Giriş}

Tarımsal üretimi arttırmak için tarımsal uygulamalar artmaya başlamış, bu durum daha fazla kimyasal madde kullanımı ve aşırı sulama ile verimli toprakların bozulmasına ve azalmasına yol açmıştır. Aynı zamanda ürün kalitesinin düşmesine de neden olmaktadır. Yapılan bu tarımsal uygulamaların yoğunlaştırılması, sulamalardan kaynaklı tuz stresi ve bor toksisitesi gibi yeni bazı sorunlara yol açmaktadır.

Tuzun bitkiler üzerindeki etkileri, su ve iyon alımı, fotosentez hızı, ozmotik etki ve oksidatif metabolizma vb. gibi bazı fizyolojik etkileri araştırılırken (Liu ve ark., 2014), yüksek tuzun bitkiler üzerindeki etkileri hala araştırılmaya devam etmektedir. Tuzun bu etkileri bitkisel üretimde de önemli kayıplara yol açabildiği düşünülmektedir.

Tuz stresi hem ozmotik hem de iyon alımını doğrudan etkilemesiyle, su ve besin alımını önemli ölçüde kısıtlamaktadır (Ashraf 2004; Khan ve ark., 2012; Ahmed ve ark., 2015). Tuz stresine maruz kalan bitkilerin sitozollerin de fazla oranda $\mathrm{Na}^{+}$birikmesi, hücre membranların da zarara yol açarak, elektiksel sızıntıya neden olmaktadır. Bu durum; $\mathrm{CO}_{2}$ asimilasyonu, lipid metabolizması, protein metabolizması ve $\mathrm{N}$ asimilasyonu dahil olmak üzere sitozoldeki metabolik aktiviteleri olumsuz yönde etkilemektedir (Ahmad 2010, Pandol ve ark., 2012, Ahmad ve ark., 2014).

Bitki büyümesi için gerekli olan besin elementlerinden biri olan bor (B) elementi özellikle, kurak ve yarı kurak alanlarda toksik seviyelerde bulunur (Roessner ve ark., 2006; Pardossi ve ark., 2015). Bazik karakterli topraklar kil mineralleri arasına B adsorbe ederek, B elverişliliğini azaltırken, sulama suyundaki $B$ ile bu gereksinim karşılanabilmektedir. Bor'un topraktan yıkanarak uzaklaşması yok denecek kadar az olmasından dolayı, tuzlu ve sodik topraklarda bor toksisitesi, bor noksanlığına göre daha olasıdır (Aydemir, 1997). B noksanlığı gübreleme yoluyla çözülebilirken, B toksisitesini çözmek zor bir sorundur. Bunun nedeni, bor'un yüksek seviyelerde bulunmasının bitkiler üzerindeki olumsuz etkileri, yıllık yağışın $550 \mathrm{~mm}$ olduğu bölgelerde geri dönüşümlü değildir. Kurak bölgelerde ise düşük yağış nedeniyle kök bölgesinde ve toprak profilinde yarayışı bor sınırlıdır (McDonald ve ark., 2010). B noksanlığı ile toksisitesi arasındaki sınır değerleri oldukça yakın olduğundan, B seviyesinin biraz yüksek olması bitkiler için toksik seviyede olmasına yeterlidir (Herrera-Rodríguez ve ark., 2010). Kurak ve yarı kurak alanlarda oluşan B toksisitesi bitki gelişimini sınırlayan önemli faktörlerden biridir. Yüksek B konsantrasyon kaynağı olarak bor, yer altı suları, toprakta doğal olarak bulunan, sulama suyu ve gübreleme ile toprakta bor miktarı arttırılmaktadır (Tas ve ark., 2016; Liu ve ark., 2015). Yüksek bor bulunan topraklarda yetişen bitkiler de bor toksisitesinin etkileri; bitki köklerinin, sürgünlerin ve stoma iletkenliğinin azalması ile fotosentez aktivitesi, klorofil içeriğinin azalması, hücre zarının lipidlerinin ve geçirgenliğinin zararlanması ile bitki savunma sisteminde meydana gelen değişiklik şeklinde sıralanabilir (Li ve ark., 2017; MachoRivero ve ark., 2017; Hossain ve ark., 2015; Liu ve ark., 2017). Bor toksisitesi, bitki yapraklarının uç kısmından başlayarak kenarlara doğru borun birikmesiyle hasara neden olur (Reid ve ark., 2004; Savić ve ark., 2013). Bu durumda farklı bitkilerde, gelişmede gerileme, yaşlı yaprakların uç ve kenarlarında nekrotik lekeler en önde gelen belirtilerdir (Shireen ve ark., 2018). Bor'un yüksek seviyeleri hücre zarına zarar vererek yaprak dokularına zarar verir. Bitki dokularında ve hücrelerinde oksidatif stresi arttırdığı artık kabul edilmektedir (Mesquita ve ark., 2016; Shah ve ark., 2017).

Bor, genellikle kurak bölgelerin sulama sularında yüksek konsantrasyonlarda bulunur (Ben-Gal ve Shani 2002). Drenajı zayıf olan tuzlu topraklar da yüksek B konsantrasyonu bulunabilir (Grieve ve Poss 2000). Yüksek oranda B ve toprak tuzluluğu, buğday (Grieve ve Poss 2000), domates ve salatalık (Alpaslan ve Güneş 2001) ve ıspanağın (Güneş ve ark., 2007a) büyümesini ve verimini sınırlayabilir. Domates ve salatalık bitkilerinin büyümesi, iki stresin ayrı ayrı uygulandığı durumla kıyaslandığında tuz stresi ve B toksisitesinin 
birlikte etkisinden daha fazla etkilenmiştir. Tuz oranının, tuza toleranslı domatesin B konsantrasyonunu düşürürken, tuza duyarlı salatalığın B konsantrasyonunu artırdığı gösterilmiştir (Alpaslan ve Güneş 2001). B'un toksik olduğu koşullarda ise elma anacında (Molassiotis ve ark., 2006) ve buğday bitkilerinde (Güneş ve ark., 2007d) ROS oranın arttığı bildirilmiştir.

Tuz stresi ve bor toksisitesinin bitki gelişimi ve verimi üzerine bağımsız etkileri bilinmesi ve literatürde yer almasına rağmen (Gupta ve ark., 1985; Munns ve Termaat 1986), bu iki stresin bütünleşik etkisine karşı bitki tepkisi üzerine yapılan araştırmalar henüz yetersizdir. Yüksek oranda tuz ve bor içeren sulama sularıyla sulama yapma (Nable ve ark., 1997) veya tuzluluğun doğal oluşumu ile yüksek bor etkisine sahip topraklarda ürünler, hem tuz stresi hem de bor toksisitesi streslerini aynı anda yaşayabilirler. Tuz stresi, birçok bitkinin gelişimini olumsuz etkileyen önemli bir sorundur (Pandolfi ve ark., 2012; RuizLozano ve ark., 2012; Rebey ve ark., 2017).

Melatonin (MT)'in bitkilerde doğal olarak sentezlenen bir moleküldür. (Iriti ve ark., 2006, Martinez ve ark., 2016). Son yıllarda MT'nin bitki içerisindeki rolünü anlamaya yönelik araştırmaların yoğunluğu önemli oranda artmıştır (Martinez ve ark., 2016). Huang ve ark., (2017) tarafından yapılan bir araştırmada MT ile işleme tabi tutulan kivi meyvesinde kadmiyum stresinin olumsuz etkilerini antioksidan savunma sistemini arttırarak zararı azalttığını ve şeftali meyvesinde soğuk hava deposunda savunmayı arttırdığı belirlenmiştir. Literatürdeki farklı araştırmalar, MT'nin strese bağlı olarak sinyal mekanizmasında rol oynadığını göstermektedir (Martinez ve ark., 2016). Allegra ve ark., (2003)'ın bildirdiğine göre MT aynı zamanda ROS süpürücü bir antioksidan olarak da bilinir Bitki büyümesinde olumlu etkisinin yanında, MT salatalıkta su stresi, donma stresi ve tuz stresi gibi olumsuz çevre şartlarında bitkinin toleransını arttırdığı düşünülmektedir (Shi ve ark., 2015). MT, yaprak yaşlanmasının yavaşlatması, kök gelişimi, sürgün büyümesi, mineral beslenmesi ve bitkilerin sıcaklık stresine karşı toleransı da dahil olmak üzere bariz fizyolojik rolleri nedeniyle biyopromoter olarak bilinir (Zuo ve ark., 2017; Liang ve ark., 2018).

Atmosferde \% 78 oranında bulunan azotun bitkiler ve diğer canlılar için yarayışlı olması için $\mathrm{NH}_{4}$ ve $\mathrm{NO}_{3}$ formlarına dönüşmesi gerekmektedir. Yarayışsız formdaki atmosfer azotunun bitkiler tarafından yararlanılabilir forma dönüşmesi için toprak içerisinde serbest yaşayan veya özellikle baklagil bitkileri ile simbiyotik olarak yaşayan bakterilerin vasıtasıyla gerçekleşebilir. Azot fiksasyonu ve organik materyallerin mikro canlılar yardımıyla mineralizasyonu sonucu bitkilerin yararlanacağı formlara dönüşür (Fritsche, 1990; Lindemann ve Glower, 2003). Baklagil bitkileri ile bu simbiyotik ilişkide bulunan bakteri Rhizobium bakterileridir. Rhizobium bakterileri hastalık, zararlılar, toprak asitliği ve su stresi gibi durumlara duyarlı olduğu ama aşılama yapılmasının gerekli olduğu ve bitkiyi dayanıklı kıldığı yapılan çalışmalarda gösterilmiştir (Adjei ve ark., 2002; Gök ve ark., 2005; Doğan ve ark., 2006).

Toprak mikrobiyal aktiviteleri ile Tarımsal verimlilik arasında yakın bir ilişki vardır. Toprak mikroorganizmaları besin ve enerji temini için yaptıkları faaliyetler sonucunda yarayışı forma geçen birçok element bitkiler için de faydalı olmaktadır. (Doğan ve ark., 2018). Rhizobial ve mikorizal aktiviteler bitki rizosfer bölgesinde karşılıklı fayda ilkesiyle mutualistik etkileşim içindedirler. Atmosfer azotunun yarayışlı formlara dönüşerek toprağa bağlanmasında bitki ve mikroorganizma arasındaki simbiyotik ilişkiden fayda sağlanır. Bu ilişki dolaylı olarak bitkinin büyüme, gelişme, hastalık ve zararlılardan korunmasında da etkili olmaktadır (Gök ve ark. 2007; Coşkan ve Doğan, 2011).

Bu çalışmada, tuz stresi ve bor toksisitesinin ayrı ayrı ve birlikte etkilerinin, melatonin uygulaması ve bakteri aşılaması sonucunda, soya fasulyesi bitkisindeki biomas ve bazı fizyolojik etkileri ile bazı toprak mikrobiyal aktiviteleri parametreleri üzerine etkileri belirlenmiştir. 


\section{Materyal ve Metot}

Araştırma, Harran Üniversitesi Toprak Bilimi ve Bitki Besleme Bölümüne ait olan cam serada 2020 yılında yürütülmüştür. Saksı denemesi olarak yürütülen bu araştırmanın bitki materyali soyadır. Denemede kullanılan toprak kampüs içerisindeki deneme alanlarından temin edilmiş olup tuzsuzdur. Toprak özellikleri Çizelge 1.'de verilmiştir. Topraklar getirildikten sonra kurutulmuş ve $2 \mathrm{~mm}$ elekten geçirilerek saksılara doldurulmuştur. Topraklar saksılara doldurulduktan sonra; tuz uygulaması ( $\mathrm{NaCl}) 100$ $\mathrm{mM}$, bor uygulaması $\left(\mathrm{H}_{3} \mathrm{BO}_{3}\right) 2 \mathrm{mM}$ olacak şekilde sulama suyuna katılarak ve melatonin $0.1 \mu \mathrm{M}$ dozunda yapraktan püskürtme şeklinde uygulanmıştır. Soya tohumlarına bulaştırılarak bakteri aşılaması yapılmış ve yapılmamış olmak üzere saksılara ekim gerçekleştirilmiştir. Çalışma 3 tekerrürlü olarak ve toplamda 4 farklı uygulama ile bunların kombinasyonları şeklinde yapılmıştır. Kullanılan bakteri Ankara Toprak Gübre ve Su Kaynakları Merkez Araştırma Enstitüsünden temin edilen ve soyaya özgü olan bradyrhizobium japonicum bakterisi kullanılmıştır. Topraklara bütün uygulamalara ekimle birlikte, dekara 12-13 kg gelecek şekilde taban gübresi olarak DAP uygulanmış ve sonrasında gübreleme yapılmamıştır.

Bitkiler istenilen boya (4-5 yaprak) geldikten sonra uygulamalar başlanmıştır. Melatonin uygulaması bitkiler strese sokulmadan bir hafta önce iki günde bir kere olmak üzere püskürtülerek toplamda 3 sefer uygulanmıştır. Takip eden haftada bitkilere bor içeren saksılara Borlu (2 mM $\mathrm{H}_{3} \mathrm{BO}_{3}$ ) sulama suyu ile, tuz içeren saksılara tuz eklenmiş sulama suyu (100 mM NaCl) ile ve her iki stresin olduğu saksılara bor ve tuzun birlikte (100 $\mathrm{mM} \mathrm{NaCl}+2 \mathrm{mM} \mathrm{H}_{3} \mathrm{BO}_{3}$ ) uygulaması yapılarak sulama gerçekleştirilmiştir. Bitkiler çiçeklenme aşamasında hasat edilmiş, gövde-kök bölgelerinin yaş-kuru ağırlıklar alınmıştır. Ardından toprak analizlere tabi tutulmuştur.
Çizelge 1. Denemede kullanılan toprak özellikleri Table 1. Soil properties used in the experiment

\begin{tabular}{|c|c|}
\hline $\mathrm{pH}$ & 7.8 \\
\hline$E C\left(\mathrm{ds} \mathrm{m^{-1 } )}\right.$ & 1.17 \\
\hline Kireç (\%) Lime (\%) & 31.5 \\
\hline $\begin{array}{l}\text { Org. Madde (\%) } \\
\text { Org. Matter (\%) }\end{array}$ & 2 \\
\hline Bünye & Killi-tın \\
\hline KDK (me 100gkt $\left.{ }^{-1}\right)$ & 38.5 \\
\hline $\mathrm{P}\left(\mathrm{kg} \mathrm{da}^{-1}\right)$ & 4.4 \\
\hline $\mathrm{Fe}\left(\mathrm{mg} \mathrm{kg}^{-1}\right)$ & 1.28 \\
\hline $\mathrm{Mn}\left(\mathrm{mg} \mathrm{kg}^{-1}\right)$ & 1.26 \\
\hline $\mathrm{Cu}\left(\mathrm{mg} \mathrm{kg}^{-1}\right)$ & 0.44 \\
\hline $\mathrm{Zn}\left(\mathrm{mg} \mathrm{kg}^{-1}\right)$ & 0.74 \\
\hline$B\left(\mathrm{mg} \mathrm{kg}^{-1}\right)$ & 0.14 \\
\hline
\end{tabular}

\section{Bitki yaş ve kuru ağırlıkları}

Bitkiler hasat sırasında, her saksıdaki bitki kök boğazından kesilmiş ve kesilen bitkilerin kök ve kök üstü aksamları ayrı ayrı tartılarak bitki yaş ağırlıkları alınmıştır. Sonraki aşamada bitkiler 70 ${ }^{\circ} C^{\prime}$ ye ayarlanmış olan etüvde kurutulmuş ve kuru ağırlıkları alınmıştır.

\section{Dehidrogenaz enzim aktivitesi (DHA) analizi}

DHA analizi Thalman (1967)'e göre yapılmıştır. $10 \mathrm{~g}$ toprak örneği alınarak 25×250 mm'lik tüplere konuldu. $10 \mathrm{ml}$ TTC çözeltisi eklenerek çalkalandı. Tüpler pamukla kapatılarak karanlık bir ortamda 24 saat bekletildi. 24 saat sonra her tüpe $50 \mathrm{ml}$ ekstraksiyon çözeltisi eklenip karanlık ortamda 2 saat bekletildi. Daha sonra tüpler içindeki çözelti filtre edildi ve ortaya çıkan süzük 546 nm dalga boyunda spektrofotometrede okumaları yapıldı.

\section{Mikrobiyal biyomas karbon içeriği (MBC) analizi}

Toprak içerisinde MBC analizi Öhlinger (1993)'e göre yapılmıştır. $50 \mathrm{~g}$ olarak alınan toprak örneği tarla kapasitesine getirilmiştir. Örnekler ile $50 \mathrm{ml}$ kloroform içeren beher eksikatöre yerleştirilir. Eksikatörün içindeki hava motor yardımıyla boşaltıldı. 24 saat beklendikten sonra örnekler çıkartıldı. Çıkartılan örnekler potasyum sülfat çözeltisi ile 1:5 oranında karıştırılarak 30 dakika çalkalamaya bırakıldı. Çalkalama işleminden sonra örnekler süzülerek organik madde tayini yapıldı.

\section{Toprak solunumu $\left(\mathrm{CO}_{2}\right)$ analizi}

$\mathrm{CO}_{2}$ üretimi analizi Isermayer

yöntemine göre yapılmıştır. $100 \mathrm{~g}$ alınan toprak 
örneği içerisinde $50 \mathrm{ml}$ barit çözelti bulunan ısermayer kavanozuna konularak hava almayacak şekilde ağzı kapatıldı ve 24 saat beklendi. Topraksız olarakta bir tane tanık yapıldı. Fenal ftaleyn damlatılarak pembe renk oluşturuldu. Pembe renk renksize dönüşene dek $\mathrm{HCl}$ ile titrasyon edildi.

\section{Araştırma Bulguları ve Tartışma}

Araştırma uygulamaları soyada kök üstü yaş ağırlığında istatistiksel açıdan ( $P \leq 0.05)$ önemli farklılıklar yaratmıştır (Şekil 1). Tuz ve bor stresi koşullarında belirlenen bitki kök üstü yaş ağırlığı değerleri düşüşler gösterirken, kontrol koşullarında MT ve BA uygulamalarına rağmen önemli farklılıklar oluşmamıştır. Bununla beraber TS ve BT etkisi altındaki bitkilerin yaş ağırlığı değerleri önemli farklılıklara neden olmuştur. En düşük değerler TS+BT uygulamalarında belirlenirken bunu sırasıyla BT ve TS uygulamaları izlemiştir. TS etkisindeki kök üstü yaş ağırlığı değerleri $2.05 \mathrm{~g} \mathrm{bitki}^{-1}$ (-MT) ile $2.44 \mathrm{~g} \mathrm{bitki}^{-1}$ (+MT+BA) olarak belirlenmiştir. Benzer şekilde BT ve TS+BT uygulamaları altındaki değerler sırasıyla 1.23 (+MT) ile $1.74(+\mathrm{MT}+\mathrm{BA})$ ve $1.03(-\mathrm{MT})$ ile 1.16 (+MT+BA) olarak belirlenmiştir.

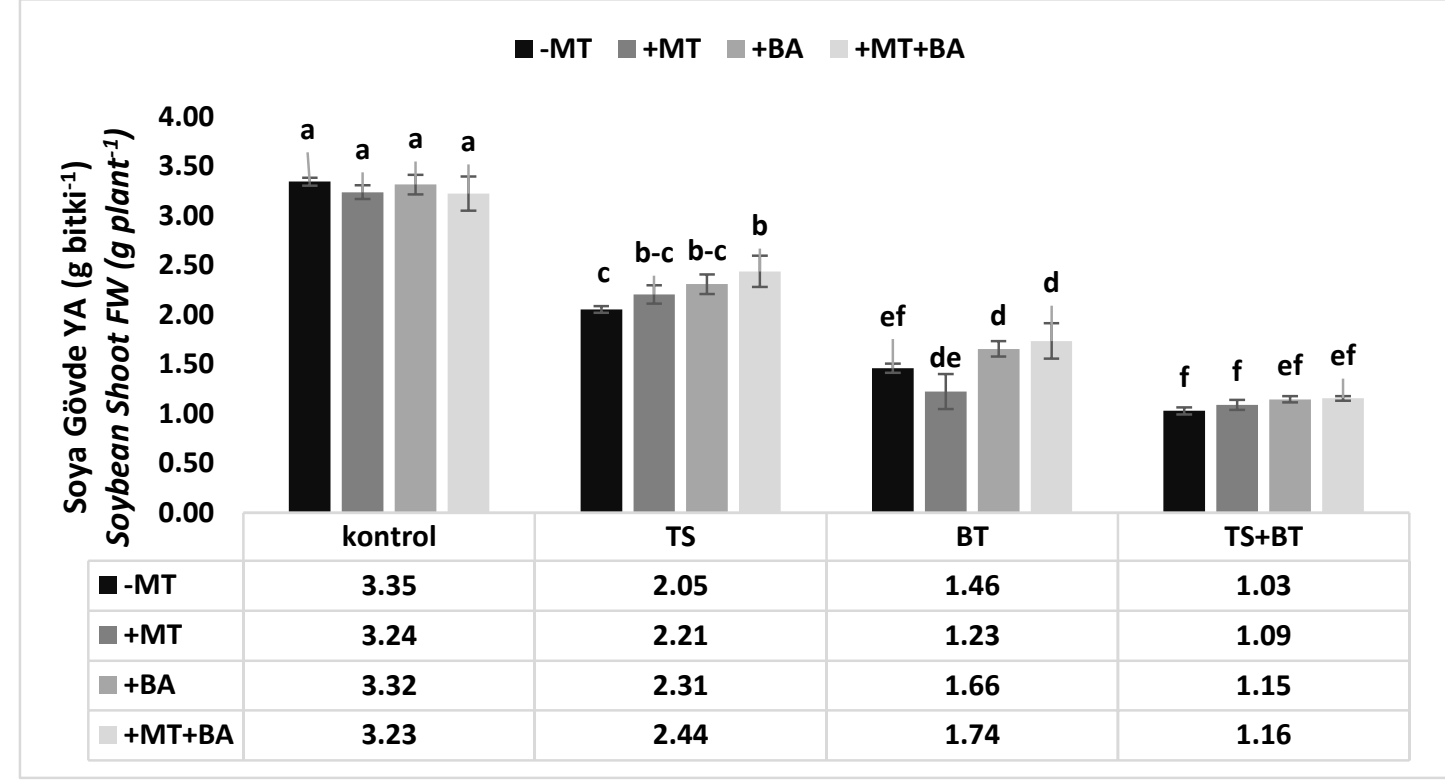

Şekil 1. Uygulamaların soya bitkisi gövde yaş ağırlık sonuçları

Figue 1. Soybean plant stem wet weight results of the applications

$\mathrm{K}$ : sadece besin solüsyonu ile beslenmiş muamele; $\mathrm{MT}$ : yapraktan 0,1mM melatonin uygulaması; BT: $2 \mathrm{mM} \mathrm{H}_{3} \mathrm{BO}_{3}$; TS (SS): $100 \mathrm{mM} \mathrm{NaCl}$; BA: Bakteri aşılanmış

Gövde yaş ağırlığı değerleri ile kök yaş ağırlığı değerleri benzer sonuçlar vermiştir (Şekil 2). Bununla beraber TS ve BT etkisinde olmayan uygulamaların bitki yaş kök ağılığı değerleri arasında önemli bazı farklılıklara neden olduğu belirlenmiştir. MT ve BA uygulamaları stres ve normal koşullarda yaş kök ağırlığı değerlerini artırmıştır. Normal koşullarda elde edilen sonuçlar daha yüksek bulunmuş ve bunu sırasıyla TS, TS+BT ile BT koşulları izlemiştir. En düşük değer $1.01 \mathrm{~g}$ bitki $^{-1}$ olarak -MT+TS+BT uygulamalarında en yüksek değer ise 2.42 olarak MT+BA uygulamalarında belirlenmiştir. 


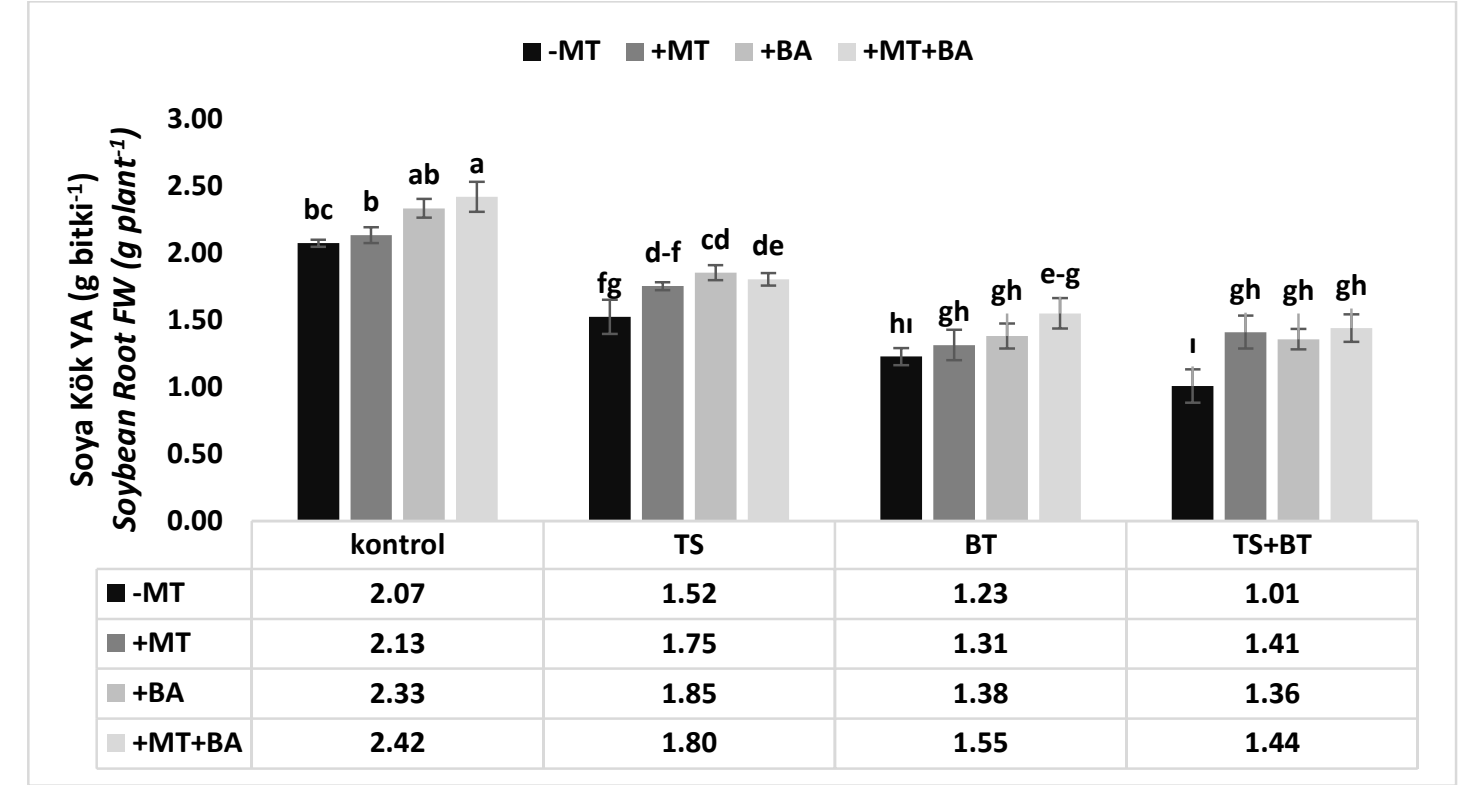

Şekil 2. Uygulamaların soya bitkisi kök yaş ağırlık sonuçları

Figure 2. Soybean plant root wet weight results of the applications

$\mathrm{K}$ : sadece besin solüsyonu ile beslenmiş muamele; $\mathrm{MT}$ : yapraktan 0,1mM melatonin uygulaması;

BT: $2 \mathrm{mM} \mathrm{H}_{3} \mathrm{BO}_{3}$; TS (SS): 100mM NaCl; BA: Bakteri aşılanmış

Uygulamaların kök üstü kuru ağırlıklarına etkilerinin görüldüğü Şekil 3' e göre, tuz ve bor toksisitesi streslerinden olumsuz yönde etkilenen bu parametre değerleri bakteri aşılaması ve MT uygulamaları ile artışlar göstermiştir. En düşük ve en yüksek kök üstü ağırlık değerleri sırasıyla $0.96 \mathrm{~g}$ bitki $^{-1}$ olarak TS+BT uygulamasında ve $1.38 \mathrm{~g} \mathrm{bitki}^{-}$ ${ }^{1}$ olarak kontrol uygulamasında belirlenmiştir.

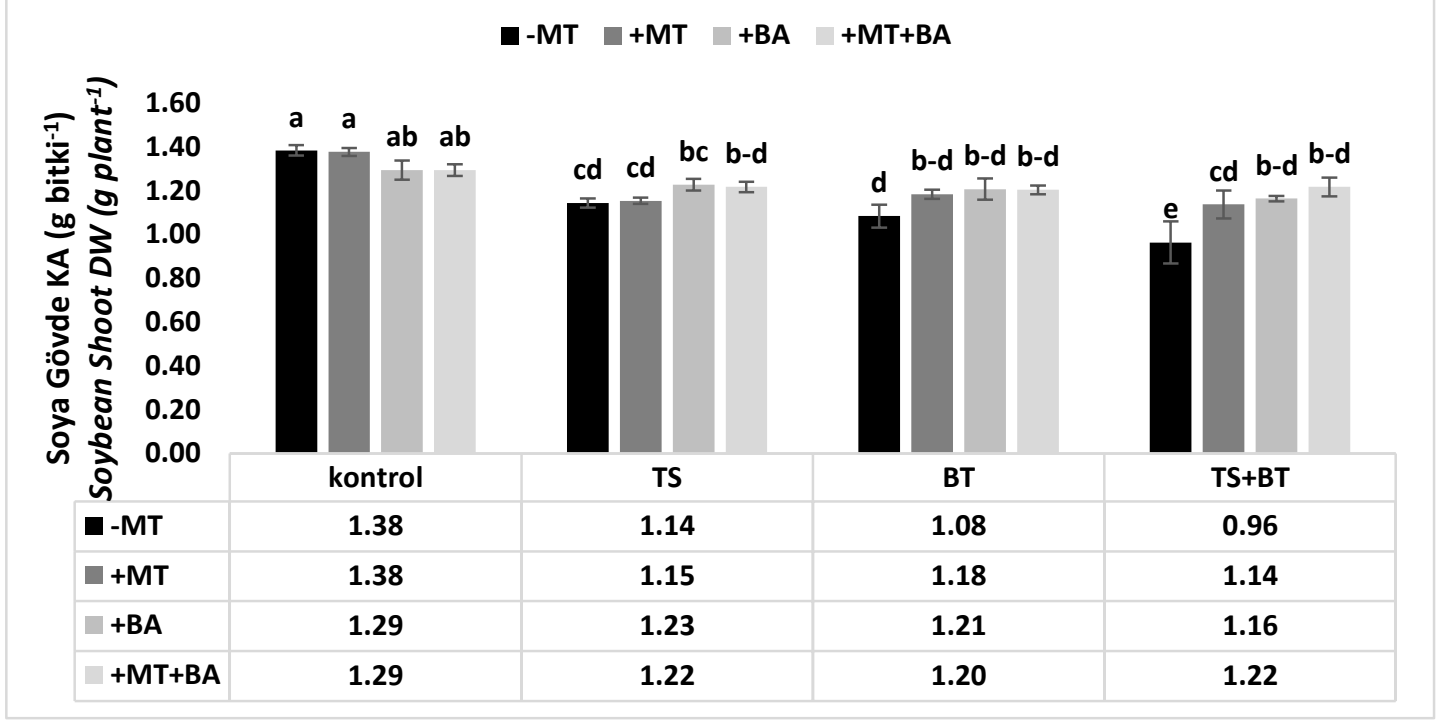

Şekil 3. Uygulamaların soya bitkisi gövde kuru ağırlık sonuçları

Figure 3. Soybean plant stem dry weight results of applications

$\mathrm{K}$ : sadece besin solüsyonu ile beslenmiş muamele; $\mathrm{MT}$ : yapraktan 0,1mM melatonin uygulaması; $\mathrm{BT}$ :

$2 \mathrm{mM} \mathrm{H}_{3} \mathrm{BO}_{3}$; TS (SS): $100 \mathrm{mM} \mathrm{NaCl}$; BA: Bakteri aşılanmış

Kök kuru ağırlık değerleri tuz ve borun stres koşullarından önemli $(\mathrm{P} \leq 0.05)$ derecede etkilenmiş olup (Şekil 4) değerler kontrol uygulamalarına göre düşmüştür. Kontrol uygulamalarında belirlenen kök kuru ağırlık değerleri 0.92-0.97 $\mathrm{g} \mathrm{bitki}^{-1}$ arasında değişimler gösterirken stres koşulları altındaki değerler 0.14$0.28 \mathrm{~g} \mathrm{bitki}^{-1}$ arasında değişimler göstermiştir. 


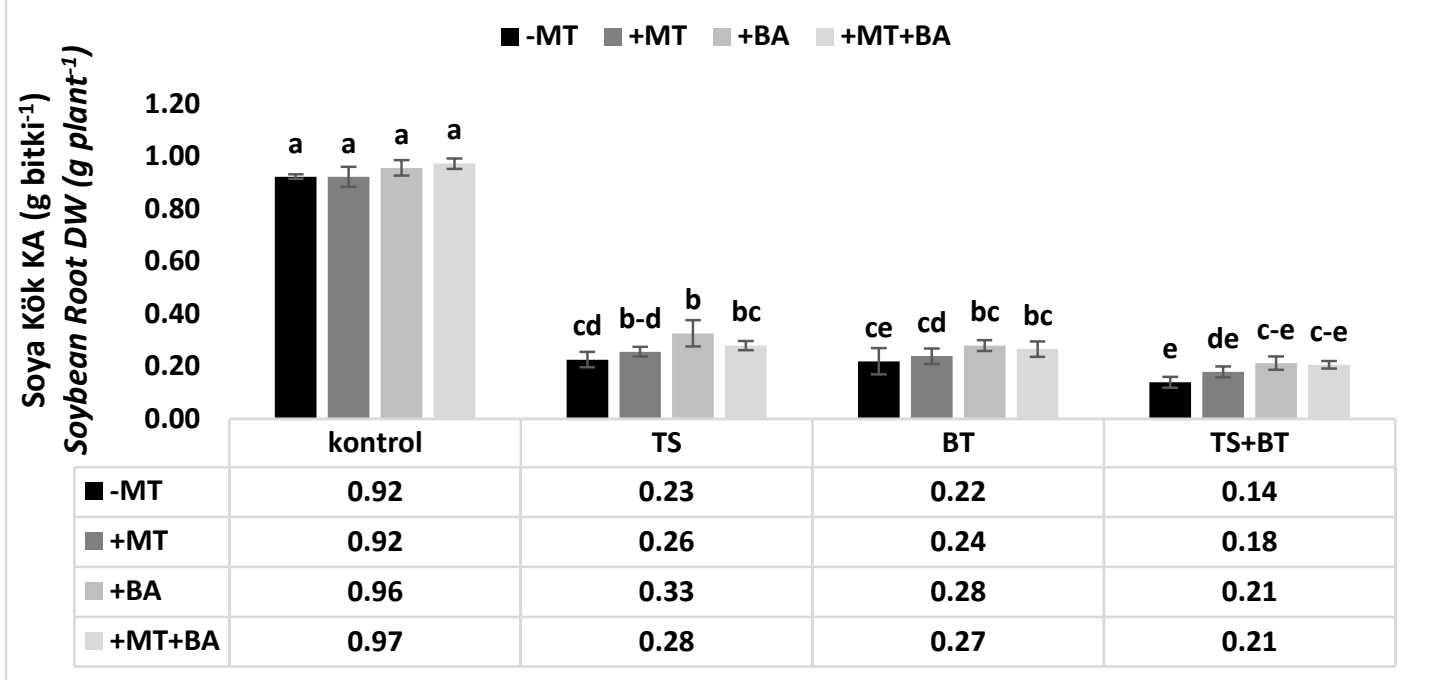

Şekil 4. Uygulamaların soya bitkisi kök kuru ağırlık sonuçları

Figure 4. Soybean plant root dry weight results of applications

$\mathrm{K}$ : sadece besin solüsyonu ile beslenmiş muamele; $\mathrm{MT}$ : yapraktan 0,1mM melatonin uygulaması; $\mathrm{BT}$ : $2 \mathrm{mM} \mathrm{H}_{3} \mathrm{BO}_{3}$; TS (SS): $100 \mathrm{mM} \mathrm{NaCl}$; BA: Bakteri aşılanmış

Yapılan tuz ve bor uygulamaları bitki biomasında ve toprak mikrobiyal aktiviteye önemli oranda etkilediği sonucuna varılmıştır. Soya bitkisi yaş ve kuru ağırlıkları incelendiğinde (Şekil 1, 2, 3, 4), bireysel olarak stresler incelendiğinde toksik seviyede bulunan bor ile yüksek oranda tuz, bitki biomas içeriğinde önemli azalmaya sebep olmuştur. iki stresin birlikte uygulaması ise (TS+BT) bitki biomasına en yüksek hasarı vermiştir. Yapılan bakteri aşılaması ise soya bitkisini stres etkilerine karşı direnç kazandırmış ve dışarıdan MT uygulaması ile bu direncin desteklendiği sonucuna varılmıştır. Gülle (2005) soya bitkisinde yaptığı çalışmada, farklı dozlarda tuz uygulamış ve farklı bakteri suşları ile aşılama yapmıştır. Elde ettiği sonuçlarda, tuz konsantrasyonu artışı ile bitki biomasında düşüşler yaşanmıştır. Yapılan bakteri aşılamaları ise bitki ağırlıklarını stresin zararlı etkilerine karşı önemli oranda arttırmıştır. Tuz etkisi altındaki soyada farklı bakteri suşları ile aşılamanın sonuçlarının araştırıldığı bir başka çalışmada, uygulanan bütün bakteriler tuza karşı bitki gelişimini farklı oranlarda da olsa arttırdığı sonucuna varılmıştır (Dardanelli ve ark., 2008). Farklı bor düzeylerinin ağır ve hafif bünyeli topraklarda soya bitkisinin nasıl etkilendiğinin araştırıldığı bir denemede, düşük düzeylerde borun bitki ağırlıklarını arttırdığı fakat konsantrasyon artışı ile bitki ağırlığında düşüler olduğunu bildirmişlerdir. Toprak bünyeleri açısından kıyaslandığında kumlu topraklarda killi topraklara göre bitki gelişiminin daha iyi olduğu ve bordan daha az etkilendiği belirlenmiştir (Cömert ve Kale Çelik, 2017). Bu amaçla yapılan birçok çalışma vardır (Kaya ve ark., 2018; Eggert ve Wirén 2017; Martinez ve ark. 2016). Yapılan çalışmalar elde ettiğimiz bulguları destekler niteliktedir.

Araştırma sonuçlarına göre bakteri aşılaması yapılmayan uygulamalarda nodül oluşumu gerçekleşmemiştir (Şekil 5). Bakteri aşılaması yapılmış ve MT uygulanmış uygulamalarda ise nodül sayısı değerleri daha yüksek bulunmuştur. En yüksek nodül sayısı sonuçları kontrol topraklarında belirlenirken tuz ve bor stres koşulları nodül oluşumunu olumsuz yönde etkilemiştir. 


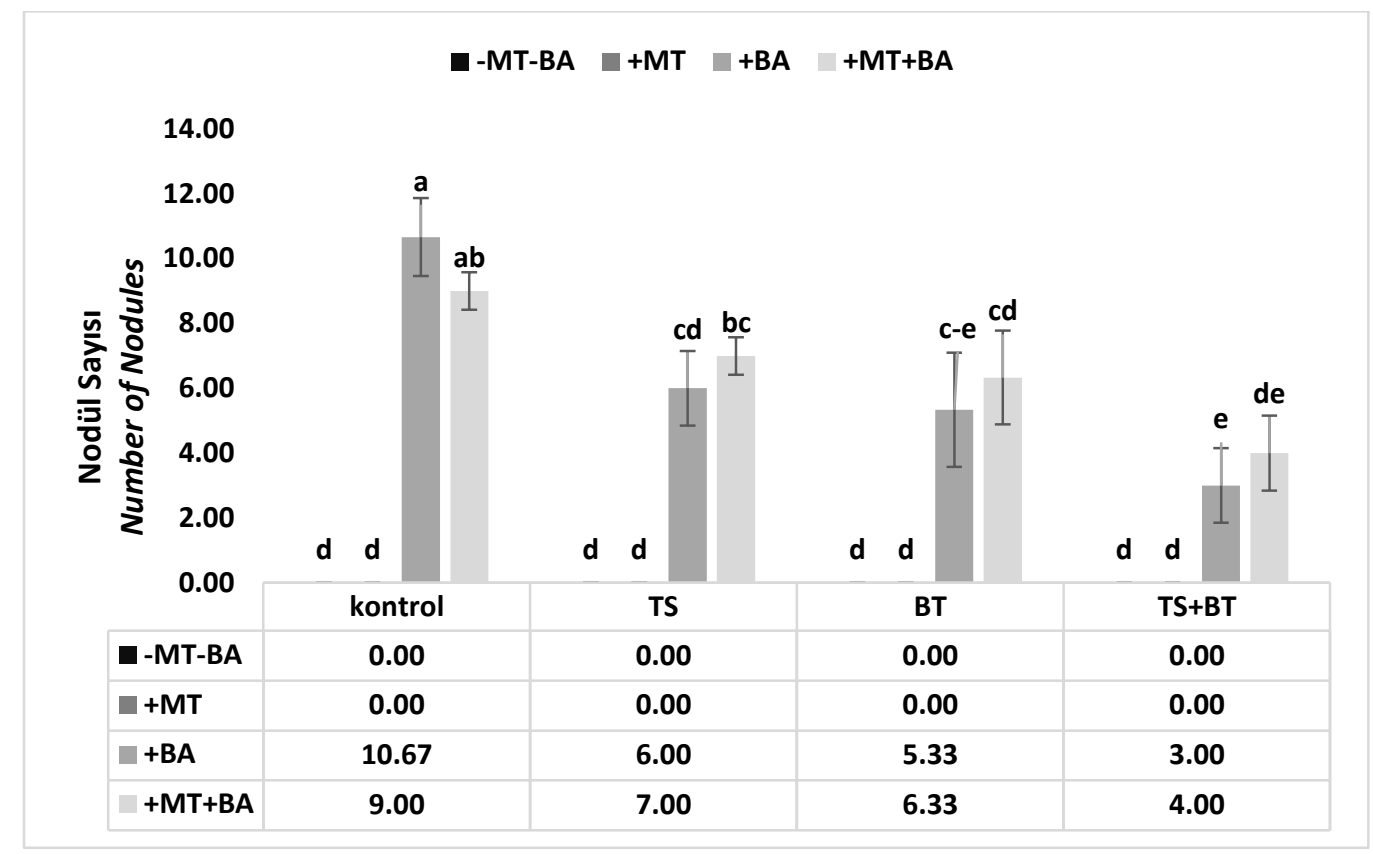

Şekil 5. Uygulamaların soya bitkisi nodül sayısı sonuçları

Figure 5. Soybean plant nodule count results of the applications

$\mathrm{K}$ : sadece besin solüsyonu ile beslenmiş muamele; $\mathrm{MT}$ : yapraktan 0,1mM melatonin uygulaması; BT: $2 \mathrm{mM} \mathrm{H}_{3} \mathrm{BO}_{3}$; TS (SS): $100 \mathrm{mM} \mathrm{NaCl}$; BA: Bakteri aşılanmış

En yüksek nodül BA uygulamasında bulunmuştur. Stres etkileri nodül sayısında düşüşlere neden olmuştur. Yapılan MT uygulaması tek başına etkili olmazken, BA uygulamasına destek verdiği ve strese direnci arttırarak nodülasyonda etkili olduğu sonucu ortaya çıkmaktadır. Singleton ve Bohlool, (1984) 3 farklı tuz konsantrasyonunun ve bakteri aşılamasının soya bitkisi nodül sayısına etkileri araştırımıştır. Araştırma sonunda tuz konsantrasyonunun artması ile nodül sayısında azalmalar meydana geldiği bildirilmiştir. Farklı konsantrasyonlardaki tuzun soyada azot içeriği etkilerinin araştırıldığı çalışmada, tuz konsantrasyonu artışı ile azot içeriğinde ne nodül sayısında düşüşlerin yaşandığını ve bunun önemli bulunduğunu bildirilmiştir (Amirjani, 2010). Dardanelli ve ark., (2008) tuz stresine karşı bakteri aşılamasının soya bitkisinde etkilerini araştırmışlardır. Aşılama ile kök gelişimi artmış ve nodülasyon oluşmuştur. Stres etkisi altında ise nodül sayısında düşüş gözlenmiştir.

Dehidrogenaz enzim aktivitesi sonuçlarını incelediğimizde (Şekil 6), en yüksek değerleri kontrol topraklarında verirken, 578.07 ( $\mu \mathrm{g}$ TPF 10${ }^{1}$ gkt.) ile BA uygulaması olarak bulunmuştur. Tüm uygulamalarda bakteri aşılaması ve MT uygulamalarıyla artışlar tespit edilmiştir. Yapılan uygulamaların toprak mikrobiyal aktivitelerinden biri olan DHA içeriğine etkileri incelendiğinde (Şekil 6), uygulanan stres etmenlerinden tekil olarak tuz stresinin (TS) bor toksisitesi 'ne (BT) göre daha fazla zarar vererek bitki rizosfer bölgesindeki DHA içeriğini önemli oranda azalttığı belirlenmiştir. En yüksek zararı ise TS+BT birlikte uygulaması en düşük DHA içeriği sonucunu ortaya çıkarmıştır. Yapılan bakteri aşılaması (BA) ise melatonin (MT) uygulamasına göre stresin zararlı etkilerini indirgemede daha etkili olduğu sonucuna varılmıştır. Yine en olumlu etki BA+MT birlikte uygulamasından elde edilmiştir. DHA topraktaki mikrobiyal aktivite açısından önemli bir göstergedir. Bu yüzdendir ki kalite analizlerinde kullanılan etkili bir sonuçtur (Kumari ve ark., 2013; Doğan, 2012). 


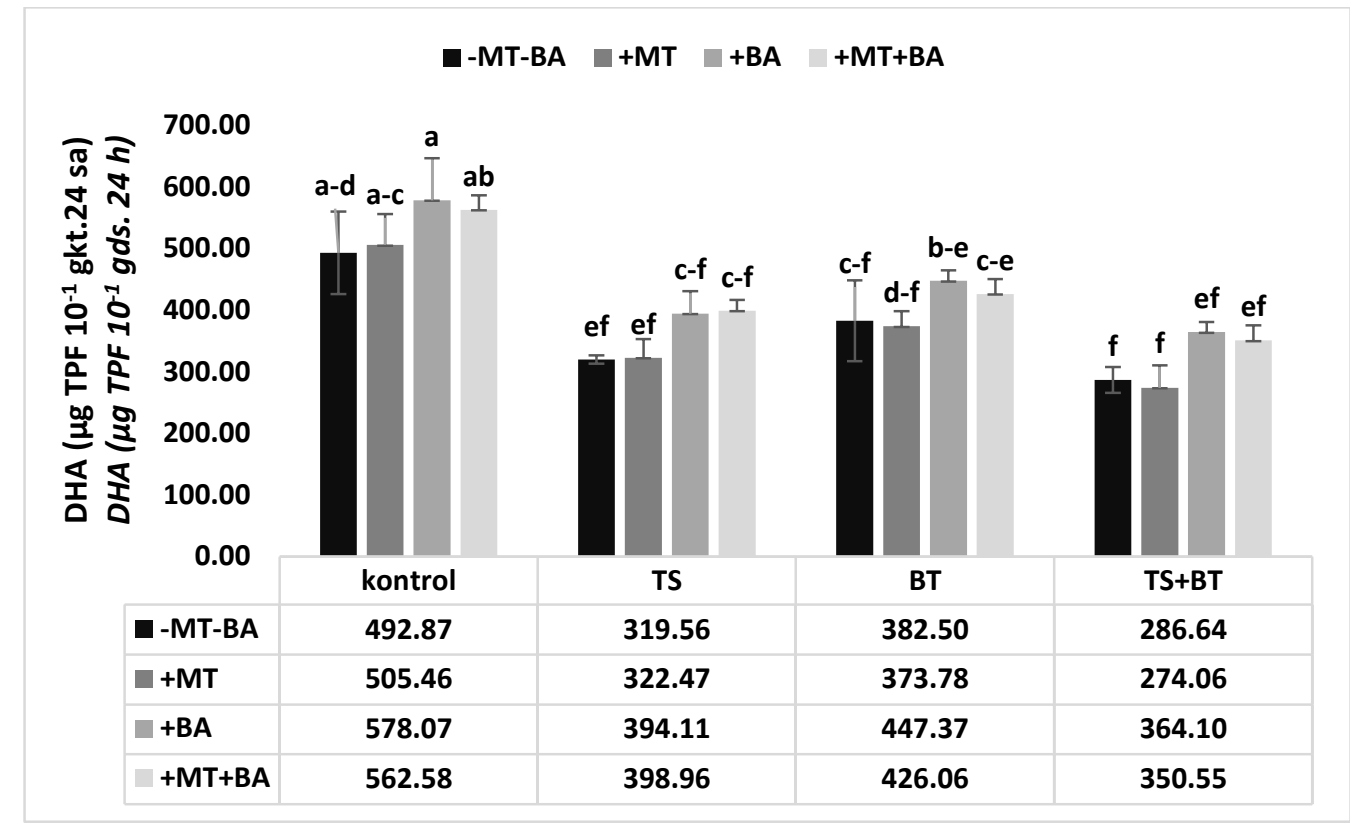

Şekil 6. Uygulamaların soya bitkisinde DHA aktivite sonuçları

Figure 6. DHA activity results in soybean plant of the applications

$\mathrm{K}$ : sadece besin solüsyonu ile beslenmiş muamele; $\mathrm{MT}$ : yapraktan 0,1mM melatonin uygulaması; BT: $2 \mathrm{mM} \mathrm{H}_{3} \mathrm{BO}_{3}$; TS (SS): $100 \mathrm{mM} \mathrm{NaCl}$; BA: Bakteri aşılanmış

Mikrobiyal biyomas karbon içeriği sonuçları şekil 7'de verilmiştir. En yüksek değerler 194.41 ( $\mu$ g TPF $10^{-1}$ gkt.24 sa) ile BA uygulaması olarak bulunmuştur. Stres etkileri MBC içeriğini kontrole göre önemli oranda düşürmüş olmasına rağmen tüm uygulamalarda bakteri aşılaması ve MT uygulamalarıyla artışlar tespit edilmiştir.

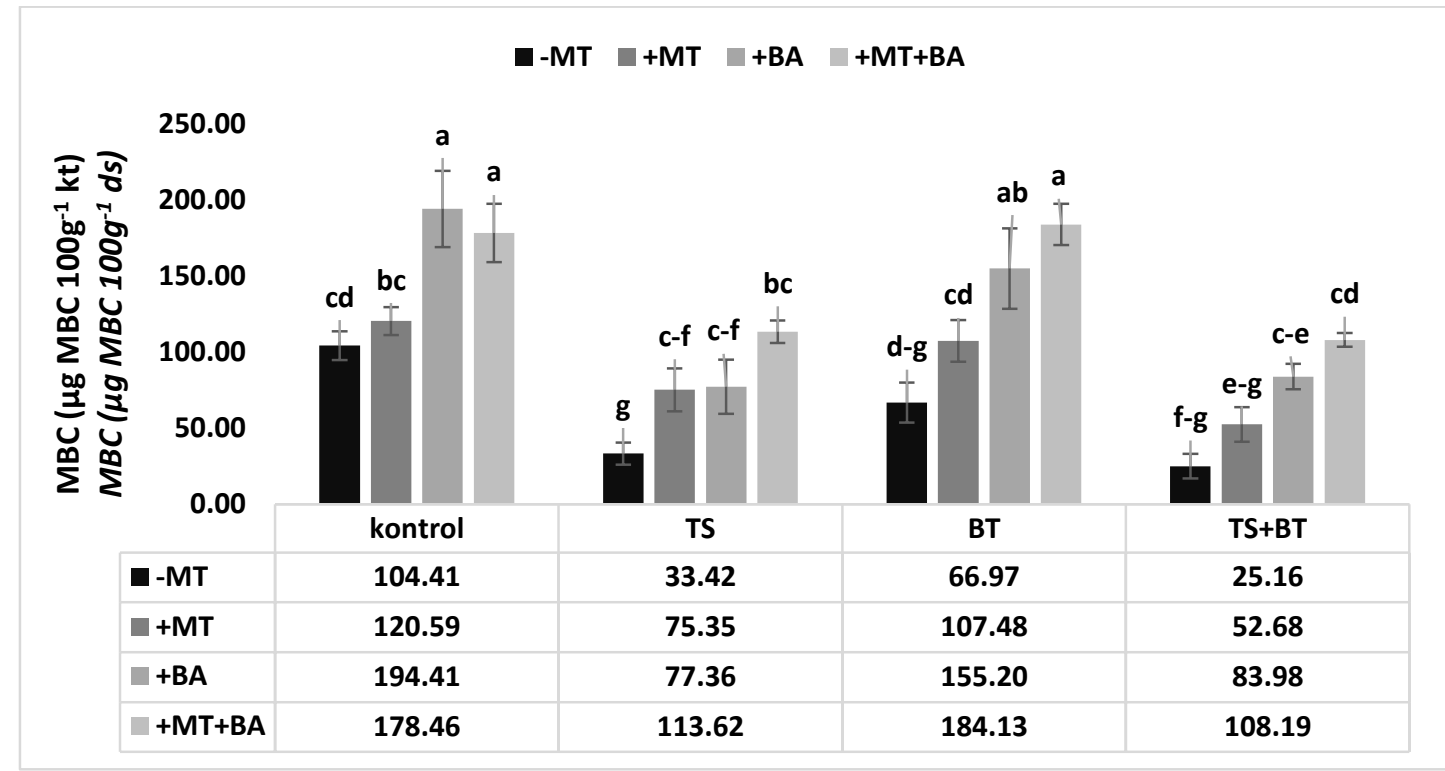

Şekil 7. Uygulamaların soya bitkisinde MBC aktivite sonuçları Figure 7. MBC activity results in soybean plant of applications

$\mathrm{K}$ : sadece besin solüsyonu ile beslenmiş muamele; $\mathrm{MT}$ : yapraktan 0,1mM melatonin uygulaması; $\mathrm{BT}$ : $2 \mathrm{mM} \mathrm{H}_{3} \mathrm{BO}_{3}$; TS (SS): $100 \mathrm{mM} \mathrm{NaCl}$; BA: Bakteri aşılanmış

Toprak mikrobiyal aktivite göstergesi olarak yapılan MBC analiz sonuçlarına bakıldığında (Şekil 7), en düşük $M B C$ içeriğini çift stres (TS+BT) uygulamasında oluştuğu, ardından bireysel streslerden ise TS uygulamasının en düşük değeri verdiği sonucuna varılmıştır. En önemli etkiyi BA uygulaması yaparken, MT uygulamasının da stres etkisini istatistiki olarak ( $\mathrm{P} \leq 0.05)$ azaltmada etkili olduğu belirlenmiştir. Bitki rizosfer bölgesindeki toprak mikrobiyal aktivitelerinden toprak solunumu $\left(\mathrm{CO}_{2}\right)$ sonuçları şekil $8^{\prime}$ de verilmiştir. 


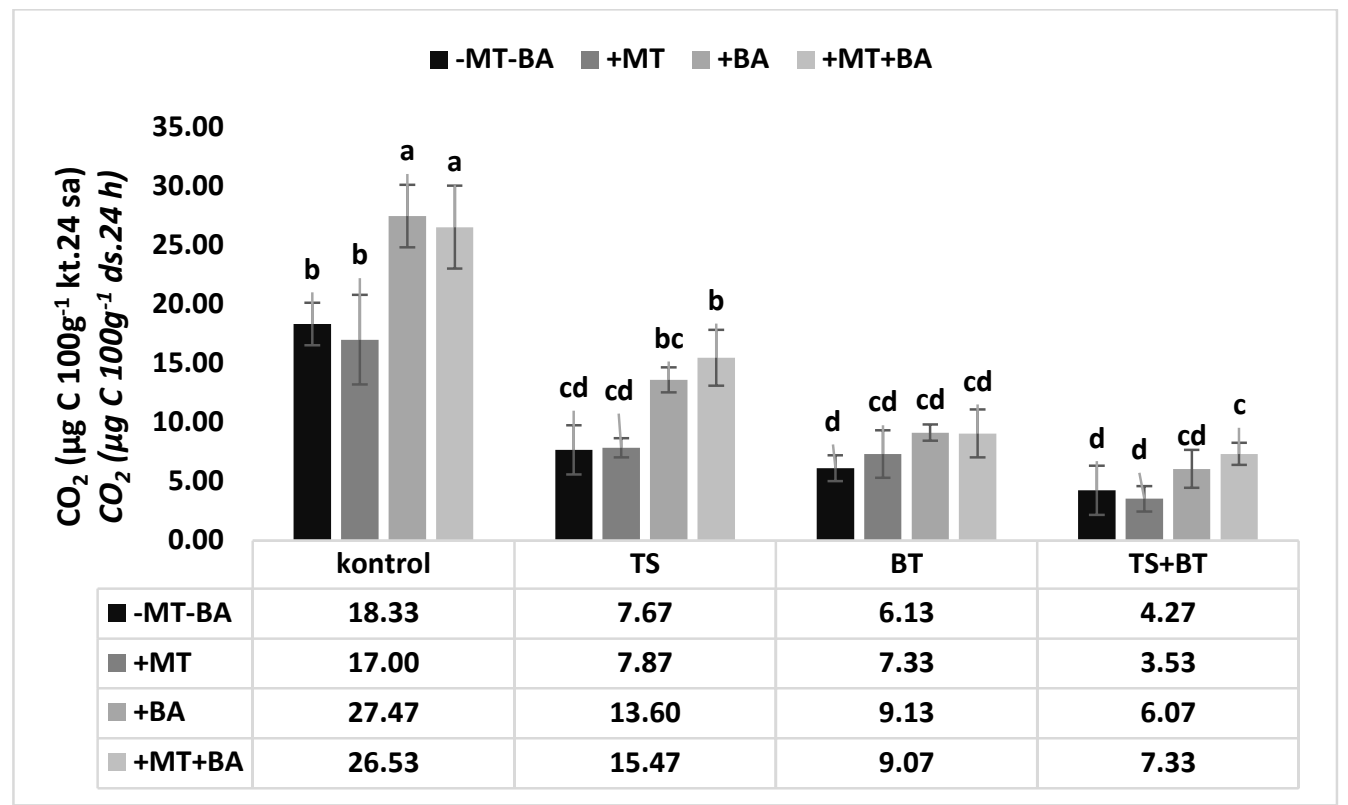

Şekil 8. Uygulamaların soya bitkisinde $\mathrm{CO}_{2}$ aktivite sonuçları

Figue 8. $\mathrm{CO}_{2}$ activity results of applications in soybean plant

$\mathrm{K}$ : sadece besin solüsyonu ile beslenmiş muamele; $\mathrm{MT}$ : yapraktan 0,1mM melatonin uygulaması;

BT: $2 \mathrm{mM} \mathrm{H}_{3} \mathrm{BO}_{3}$; TS (SS): $100 \mathrm{mM} \mathrm{NaCl}$; BA: Bakteri aşılanmış

En yüksek değerler 27.47 ( $\mu \mathrm{g}$ TPF $10^{-1}$ gkt.24 sa) ile BA uygulaması olarak bulunmuştur. Stres etkileri MBC içeriğini kontrole göre önemli oranda düşürmüş fakat tüm uygulamalarda bakteri aşılaması ve MT uygulamalarıyla artışlar tespit edilmiştir. TS+BT uygulamasının $\mathrm{CO}_{2}$ içeriğini önemli oranda azalttığı sonucuna varılmıştır. Bireysel streslerden BT istatistiki olarak çift stresle (TS+BT) aynı sonucu vermiştir. Yapılan BA ve MT uygulamaları stres etkilerini hafifletmede önemli etki etmiştir.

Tuz stresi ve bor toksisitesi gibi Abiyotik stres etmenleri Baklagil bitkilerini etkilemektedir (Zahran, 1991). Tuz etkisi altında yetişen bitkilerde gelişme hızlarındaki düşüler bazı enzimleri, toplam proteini ve nükleik asitleri azaltmaktadır. Toksik zarar veren bazı iyonlar bitkilerin dokularında birikmekte ve enzim aktivitesinde zarara neden olmaktadır (Bordeleau ve Prevost, 1994). Bunların yanında Baklagil bitkilerinde nodül oluşumuna, aktivitesine ve toprak mikrobiyal aktivitesine olumsuz etkileri olmaktadır. Yonca bitkisinde yapılan bir çalışmada tuz stresi altında bitkiye yapılan aşılamanın bitki toleransını arttırdığı sonucuna varılmıştır (Sprent, 1989). Mercimek bitkisine yapılan aşılamanın, nodül sayısı, bitki bioması, azot içeriği ve toprak mikrobiyal aktivitesinde önemli farklılık olduğunu ortaya koymuşlardır (Bremer ve ark., 1990). Kataria ve ark., (2019) soya bitkisinde yaptıkları çalışmada 4 farklı $\mathrm{NaCl}$ konsantrasyonu kullanış ve bitkiye etkileri incelenmiştir. En yüksek konsantrasyon olan $100 \mathrm{mM} \mathrm{NaCl}$, bitki biomas içeriğini ve toprak mikrobiyal aktiviteyi düşürdüğünü belirlemişlerdir.

\section{Sonuç}

Sonuç olarak bakıldığında, tuz stresi ve bor toksisitesinin bireysel etkileri dışında özellikle birlikte etkileri soya bitkisinin biomas içerikleri ile bitki rizosfer bölgesindeki toprak mikrobiyal aktivite içeriklerini önemli oranda azalttığı sonucuna varılmaktadır. Bu stres etkilerinin ortaya çıkardığı olumsuz etkileri gidermek adına yapılan bakteri aşılaması ve melatonin uygulaması bitki biomas içeriğini ve toprak mikrobiyal aktivitesini arttırarak stresin olumsuz etkilerini azalttığı belirlenmiştir. Çift stresin (TS+BT) beraber uygulandığı çalışma sınırlı sayıda bulunmaktadır. Çalışmamızda stres etkilerine karşı $100 \quad \mu \mathrm{M}$ melatoninin uygulamasının ve özellikle soya bitkisine bakteri aşılamasının önemli olduğu vurgulanmak istenmiştir. 


\section{Ekler}

Bu çalışma birinci yazarın doktora tezi olan ve aynı zamanda Harran Üniversitesi BAP Koordinasyon Birimince desteklenen 19096 numaralı projesinden türetilmiştir.

Çıkar Çatışması Beyanı: Makale yazarları aralarında herhangi bir çıkar çatışması olmadığını beyan ederler.

Yazar katkısı: Cengiz KAYA denemeyi tasarlamış, Ali SARIOĞLU denemeyi kurmuş, Cengiz KAYA ve Ali SARIOĞLU denemeyi yürütmüş, Ali SARIOĞLU analizleri yapmış, Cengiz KAYA verileri incelemiş, Ali SARIOĞLU literatür taraması yapmış, Cengiz KAYA ve Ali SARIOĞLU makaleyi birlikte yazmışlardır.

\section{Kaynaklar}

Adjei, M. B., Quesenberry, K. H., \& Chambliss, C. G. (2002). Nitrogen fixation and inoculation of forage legumes. University of Florida. Ifas Extension. USA. Ahammed, G.J., Xu, W., Liu, A., Chen, S., 2018a. Endogenous melatonin deficiency aggravates high temperature-induced oxidative stress in Solanum lycopersicum

Ahmad, P. (2010). Growth and antioxidant responses in mustard (Brassica juncea L.) plants subjected to combined effect of gibberellic acid and salinity. Archives of Agronomy and Soil Science, 56(5), 575-588.

Ahmad, P., Ozturk, M., Sharma, S., \& Gucel, S. (2014). Effect of sodium carbonate-induced salinity-alkalinity on some key osmoprotectants, protein profile, antioxidant enzymes, and lipid peroxidation in two mulberry (Morus alba L.) cultivars. Journal of plant interactions, 9(1), 460-467.

Ahmed, I. M., Nadira, U. A., Bibi, N., Cao, F., He, X., Zhang, G., \& Wu, F. (2015). Secondary metabolism and antioxidants are involved in the tolerance to drought and salinity, separately and combined, in Tibetan wild barley. Environmental and Experimental Botany, 111, 1-12.

Allegra, M., Reiter, R. J., Tan, D. X., Gentile, C., Tesoriere, L., \& Livrea, M. A. (2003). The chemistry of melatonin's interaction with reactive species. Journal of pineal research, 34(1), 1-10.

Alpaslan, M., \& Gunes, A. (2001). Interactive effects of boron and salinity stress on the growth, membrane permeability and mineral composition of tomato and cucumber plants. Plant and Soil, 236(1), 123-128.

Amirjani, M. R. (2010). Effect of salinity stress on growth, mineral composition, proline content, antioxidant enzymes of soybean. American Journal of Plant
Physiology, 5(6), 350-360.

Ashraf, M. (2004). Some important physiological selection criteria for salt tolerance in plants. FloraMorphology, Distribution, Functional Ecology of Plants, 199(5), 361-376.

Aydemir, O. (1997). Toprak Verimliliği II, Toprak-Bitki İlişkileri. Atatürk Üniversitesi Ziraat Fakültesi Yayınları, (192), 115.

Ben-Gal, A., \& Shani, U. (2002). Yield, transpiration and growth of tomatoes under combined excess boron and salinity stress. Plant and soil, 247(2), 211-221.

Bordeleau, L. M., \& Prévost, D. (1994). Nodulation and nitrogen fixation in extreme environments. Plant and soil, 161(1), 115-125.

Bremer, E., Van Kessel, C., Nelson, L. V., Rennie, R. J., \& Rennie, D. A. (1990). Selection of Rhizobium leguminosarum strains for lentil (Lens culinaris) under growth room and field conditions. Plant and Soil, 121(1), 47-56.

Cao, S., Song, C., Shao, J., Bian, K., Chen, W., \& Yang, Z. (2016). Exogenous melatonin treatment increases chilling tolerance and induces defense response in harvested peach fruit during cold storage. Journal of agricultural and food chemistry, 64(25), 5215-5222.

CÖMERT, A., \& ÇELIK, S. K. (2017). Farklı toprak bünyelerinde sulama suyu bor düzeylerinin fasulye bitkisi verimi üzerine etkilerinin belirlenmesi. Harran Tarım ve Gıda Bilimleri Dergisi, 21(3), 323-331.

Coskan, A., \& Dogan, K. (2011). Symbiotic nitrogen fixation in soybean. Soybean Physiology and Biochemistry, 307, 167-182.

Dardanelli, M. S., de Cordoba, F. J. F., Espuny, M. R., Carvajal, M. A. R., Díaz, M. E. S., Serrano, A. M. G., ... \& Megías, M. (2008). Effect of Azospirillum brasilense coinoculated with Rhizobium on Phaseolus vulgaris flavonoids and Nod factor production under salt stress. Soil Biology and Biochemistry, 40(11), 2713-2721.

Doğan, K., Gök, M., \& Coşkan, A. (2006, March). Denitrification rated soil respiration with respect to organic subsrate applications. In Proceedings of the International Workshop for the Research Project on the Impact of Climate Changes on Agricultural Production System in Arid Areas (ICCAP), Kyoto, Japan.

DOĞAN, K., SARIOĞLU, A., ŞAKAR, E., \& KARANLIK, S. (2018). Zeytin Karasuyu, Isıl İşlem Görmüş Solucan Gübresi Ve Çiftlik Gübresi Uygulamalarının Toprak Mikrobiyal Aktivite Değişimlerine Etkisi. Ziraat Fakültesi Dergisi, 151-159.

Doğan, M. (2012). Investigation of the effect of salt stress on the antioxidant enzyme activities on the young and old leaves of salsola (Stenoptera) and tomato (Lycopersicon esculentum L.). African Journal of Plant Science, 6(2), 62-72.

Eggert, K., \& von Wirén, N. (2017). Response of the plant hormone network to boron deficiency. New Phytologist, 216(3), 868-881.

Fritsche, K. L., \& Johnston, P. V. (1990). Effect of dietary $\alpha$ linolenic acid on growth, metastasis, fatty acid profile and prostaglandin production of two murine mammary adenocarcinomas. The Journal of nutrition, 120(12), 1601-1609. 
Gök, M., Doğan, K., Coşkan, A., \& ARIOĞLU, H. (2005). Yerfıstığı Bitkisinde Bakteriyel Aşılama ile Demir ve Molibden Uygulamalarının Nodülasyon, N2Fiksasyonu ve Verime Etkisi. IV. Tarım Kongresi Bildiri Kitabı, 21-23.

Gök, M., Doğan, K., Coşkan, A., \& ARIOĞLU, H. (2007). Çukurova bölgesi yerfıstığı ekim alanlarında rhizobiyal potansiyelin belirlenmesi ve bir model denemede bakteriyel aşılama ile demir uygulamalarının nodülasyon, bitki gelişimi ve verime etkisinin araştırılması. TÜBITAKTOVAG-104 O, 363.

Grieve, C. M., \& Poss, J. A. (2000). Wheat response to interactive effects of boron and salinity. Journal of Plant Nutrition, 23(9), 1217-1226.

GÜLLE, E. D. (2005). Değişik bakteri suşları ile aşılanan soya bitkisinde tuzluluğun $n 2$ fiksasyonu ve besin elementi alımına etkisi/The effect of soil salinity on nitrogen fixation and nutrient uptake of soybean inoculated with different bacteria strains (Doctoral dissertation).

Gunes, A., Inal, A., Bagci, E. G., \& Pilbeam, D. J. (2007). Silicon-mediated changes of some physiological and enzymatic parameters symptomatic for oxidative stress in spinach and tomato grown in sodic-B toxic soil. Plant and Soil, 290(1), 103-114.

Gunes, A., Inal, A., Bagci, E. G., Coban, S., \& Sahin, O. (2007d). Silicon increases boron tolerance and reduces oxidative damage of wheat grown in soil with excess boron. Biologia Plantarum, 51(3), 571574.

Gupta, U. C., Jame, Y. W., Campbell, C. A., Leyshon, A. J., \& Nicholaichuk, W. (1985). Boron toxicity and deficiency: a review. Canadian Journal of Soil Science, 65(3), 381-409.

Herrera-Rodríguez, M. B., González-Fontes, A., Rexach, J., Camacho-Cristobal, J. J., Maldonado, J. M., \& Navarro-Gochicoa, M. T. (2010). Role of boron in vascular plants and response mechanisms to boron stresses. Plant Stress, 4(2), 115-122.

Hossain, M. F., Shenggang, P., Meiyang, D., Zhaowen, M., Karbo, M. B., Bano, A., \& Xiangru, T. (2015). Photosynthesis and antioxidant response to winter rapeseed (Brassica napus L.) as affected by boron. Pak. J. Bot, 47(2), 675-684.

Huang, X., Xia, H., Shen, Y., Wang, Q., Xu, N., Lei, Z., \& Liang, D. (2017, April). Effects of exogenous melatonin on antioxidant system in leaves of kiwifruit seedlings under cadmium stress. In 2017 6th International Conference on Energy, Environment and Sustainable Development (ICEESD 2017) (pp. 840-843). Atlantis Press.

Iriti, M., Rossoni, M., \& Faoro, F. (2006). Melatonin content in grape: myth or panacea? Journal of the Science of Food and Agriculture, 86(10), 1432-1438.

Isermeyer, H. (1952). Eine einfache Methode zur Bestimmung der Bodenatmung und der Karbonate im Boden. Zeitschrift für Pflanzenernährung, Düngung, Bodenkunde, 56(1-3), 26-38.

Kataria, S., Baghel, L., Jain, M., \& Guruprasad, K. N. (2019). Magnetopriming regulates antioxidant defense system in soybean against salt stress. Biocatalysis and Agricultural Biotechnology, 18, 101090.

Kaya, C., Akram, N. A., \& Ashraf, M. (2018). Kinetin and indole acetic acid promote antioxidant defense system and reduce oxidative stress in maize (Zea mays L.) plants grown at boron toxicity. Journal of Plant Growth Regulation, 37(4), 1258-1266.

Khan, A. S., Yu, S., \& Liu, H. (2012). Deformation induced anisotropic responses of Ti-6Al-4V alloy Part II: A strain rate and temperature dependent anisotropic yield criterion. International Journal of Plasticity, 38, 14-26.

Kumari, S. R., Mridula, G., \& Hema, K. (2013). Effect of growth regulators and weedicides as defoliants (harvest aids) on seed cotton yield of cotton. Journal of Cotton Research and Development, 27(1), 56-59.

Li, X. W., Liu, J. Y., Fang, J., Tao, L., Shen, R. F., Li, Y. L., ... \& Yu, M. (2017). Boron supply enhances aluminum tolerance in root border cells of pea (Pisum sativum) by interacting with cell wall pectins. Frontiers in plant science, 8, 742.

Liang, B., Ma, C., Zhang, Z., Wei, Z., Gao, T., Zhao, Q., ... \& Li, C. (2018). Long-term exogenous application of melatonin improves nutrient uptake fluxes in apple plants under moderate drought stress. Environmental and experimental botany, 155, 650-661.

Lindemann, W. C., \& Glover, C. R. (2003). Nitrogen fixation by legumes.

Liu, C., Lu, W., Ma, Q., \& Ma, C. (2017). Effect of silicon on the alleviation of boron toxicity in wheat growth, boron accumulation, photosynthesis activities, and oxidative responses. Journal of Plant Nutrition, 40(17), 2458-2467.

Liu, J., Wang, W., Wang, L., \& Sun, Y. (2015). Exogenous melatonin improves seedling health index and drought tolerance in tomato. Plant growth regulation, 77(3), 317-326.

Macho-Rivero, M. Á., Camacho-Cristóbal, J. J., HerreraRodríguez, M. B., Müller, M., Munné-Bosch, S., \& González-Fontes, A. (2017). Abscisic acid and transpiration rate are involved in the response to boron toxicity in Arabidopsis plants. Physiologia plantarum, 160(1), 21-32.

Martinez, V., Mestre, T. C., Rubio, F., Girones-Vilaplana, A., Moreno, D. A., Mittler, R., \& Rivero, R. M. (2016). Accumulation of flavonols over hydroxycinnamic acids favors oxidative damage protection under abiotic stress. Frontiers in plant science, 7, 838.

McDonald, G. K., Eglinton, J. K., \& Barr, A. R. (2010). Assessment of the agronomic value of $\mathrm{QTL}$ on chromosomes $2 \mathrm{H}$ and $4 \mathrm{H}$ linked to tolerance to boron toxicity in barley (Hordeum vulgare L.). Plant and Soil, 326(1), 275-290.

Mesquita, G. L., Zambrosi, F. C., Tanaka, F. A., Boaretto, R. M., Quaggio, J. A., Ribeiro, R. V., \& Mattos Jr, D. (2016). Anatomical and physiological responses of citrus trees to varying boron availability are dependent on rootstock. Frontiers in Plant Science, 7, 224.

Molassiotis, A., Sotiropoulos, T., Tanou, G., Diamantidis, G., \& Therios, I. (2006). Boron-induced oxidative damage and antioxidant and nucleolytic responses in shoot tips culture of the apple rootstock EM 9 (Malus domestica Borkh). Environmental and Experimental Botany, 56(1), 54-62.

Munns, R., \& Termaat, A. (1986). Whole-plant responses to 
salinity. Functional Plant Biology, 13(1), 143-160.

Nable, R. O., Bañuelos, G. S., \& Paull, J. G. (1997). Boron toxicity. Plant and soil, 193(1), 181-198.

Öhlinger, R. (1993). Bestimmung des Biomasse-Kohlenstoffs mittels Fumigation-Exstraktion. Bodenbiologische Arbeitsmethoden, 2, 289-311.

Pandolfi, C., Mancuso, S., \& Shabala, S. (2012). Physiology of acclimation to salinity stress in pea (Pisum sativum). Environmental and Experimental Botany, 84, 44-51.

Pardossi, A., Romani, M., Carmassi, G., Guidi, L., Landi, M., Incrocci, L., ... \& Ziliani, M. (2015). Boron accumulation and tolerance in sweet basil (Ocimum basilicum L.) with green or purple leaves. Plant and soil, 395(1), 375-389.

Rebey, I. B., Bourgou, S., Rahali, F. Z., Msaada, K., Ksouri, R., \& Marzouk, B. (2017). Relation between salt tolerance and biochemical changes in cumin (Cuminum cyminum L.) seeds. journal of food and drug analysis, 25(2), 391-402.

Reid, R. J., Hayes, J. E., Post, A., Stangoulis, J. C. R., \& Graham, R. D. (2004). A critical analysis of the causes of boron toxicity in plants. Plant, Cell \& Environment, 27(11), 1405-1414.

Roessner, U., Patterson, J. H., Forbes, M. G., Fincher, G. B., Langridge, P., \& Bacic, A. (2006). An investigation of boron toxicity in barley using metabolomics. Plant physiology, 142(3), 1087-1101.

Ruiz-Lozano, J. M., Porcel, R., Azcón, C., \& Aroca, R. (2012). Regulation by arbuscular mycorrhizae of the integrated physiological response to salinity in plants: new challenges in physiological and molecular studies. Journal of Experimental Botany, 63(11), 4033-4044.

Savić, J., Marjanović-Jeromela, A., Glamočlija, Đ., \& Prodanović, S. (2013). Oilseed rape genotypes response to boron toxicity. Genetika, 45(2), 565-574.

Shah, A., Wu, X., Ullah, A., Fahad, S., Muhammad, R., Yan,
L., \& Jiang, C. (2017). Deficiency and toxicity of boron: alterations in growth, oxidative damage and uptake by citrange orange plants. Ecotoxicology and environmental safety, 145, 575-582.

Shi, Y., Ding, Y., \& Yang, S. (2015). Cold signal transduction and its interplay with phytohormones during cold acclimation. Plant and Cell Physiology, 56(1), 7-15.

Shireen, F., Nawaz, M. A., Chen, C., Zhang, Q., Zheng, Z., Sohail, H., ... \& Bie, Z. (2018). Boron: functions and approaches to enhance its availability in plants for sustainable agriculture. International Journal of Molecular Sciences, 19(7), 1856.

Singleton, P. W., \& Bohlool, B. B. (1984). Effect of salinity on nodule formation by soybean. Plant Physiology, 74(1), 72-76.

Sprent, J. I. (1984). Effects of drought and salinity on heterotrophic nitrogen fixing bacteria and on infection of legumes by rhizobia. In Advances in nitrogen fixation research (pp. 295-302). Springer, Dordrecht.

Tas, I., Ozkay, F., Yeter, T., Gorgisen, C., \& Cosge, B. (2016). Effects of high boron containing irrigation waters on plant characteristics of basil (Ocimum basilicum L.). Gaziosmanpașa Üniversitesi Ziraat Fakültesi Dergisi, 33(3), 46-54.

Thalmann. A. (1967). Über die mikrobielle Aktivitaet und ihre Beziehungen zur Fruchtbarkeit smerkmalen einiger Ackerböden unter besonderer Berücksichtigung der Dehydrogenase aktivitaet (TTCReduktion) Diss. Giessen (FRG).

Zahran, H. H. (1991). Conditions for successful Rhizobiumlegume symbiosis in saline environments. Biology and Fertility of Soils, 12(1), 73-80.

Zuo, Z., Sun, L., Wang, T., Miao, P., Zhu, X., Liu, S., ... \& Li, X. (2017). Melatonin improves the photosynthetic carbon assimilation and antioxidant capacity in wheat exposed to nano-ZnO stress. Molecules, 22(10), 1727. 